\title{
Housing Bubbles: A Tale of Two Cities
}

\author{
(2012 version)
}

\author{
Hsiao-Jung Teng, ${ }^{\text {a }}$ Chin-Oh Chang, ${ }^{\text {b }}$ K.W. Chau, ${ }^{\mathrm{c}}$
}

Final version of the paper is available from:

http://0-www.sciencedirect.com.precise.petronas.com.my/science/article/pii/S0197397512000720

Suggested citation:

Teng, Hsiao-Jung, Chang, Chin-Oh and Chau, K.W. (2013) "Housing Bubbles: A Tale of Two Cities" Habitat International 39(3): 8-15, DOI: 10.1016/j.habitatint.2012.10.009,

*Please send comments to:

K. W. Chau, Department of Real Estate and Construction, The University of Hong Kong, Pokfulam Road, Hong Kong. Fax: (852) 2559 9457,

E-mail: hrrbckw@hku.hk

\footnotetext{
${ }^{\mathrm{a}}$ Department of Land Economics, National Chengchi University, Taipei, Taiwan. Tel:+886 -2-29387481,E-Mail:babu0910@gmail.com.

b Department of Land Economics, National Chengchi University, Taipei, Taiwan. Tel:+886 -2-29387478, e-mail:jachang@nccu.edu.tw.

c Dept of Real Estate \& Construction, The University of Hong Kong, Hong Kong.
} 


\title{
Housing Bubbles: A Tale of Two Cities
}

\author{
Hsiao-Jung Teng, ${ }^{\text {d }}$ Chin-Oh Chang, ${ }^{\text {e }}$ K.W. Chau, ${ }^{\mathrm{f}}$
}

\begin{abstract}
This study examines the impact of land tenure on housing bubbles. A housing bubble is defined as the portion of housing prices not justified by market fundamentals that determine the consumption demand for housing. While there are many factors that contribute to the formation of housing bubbles, we hypothesize that a housing bubble is likely to be bigger in a market with freehold properties than in one with leasehold properties. This is because the value of the real redevelopment option embedded in a freehold property is affected by changes market expectations to a much greater extent than its use value. Therefore a small change in market sentiment will affect the prices of housing units situated on freehold land more than those on leasehold land. We use a state-space model to empirically estimate the sizes of housing bubbles in Taipei and Hong Kong since the 1980s. The land tenure in the former is freehold, while that in the latter is leasehold. We find that the average size of housing bubbles is larger in Taipei during the period of observation, which supports our hypothesis. The change in Hong Kong's land policy after July 1997 has effectively turned its land tenure system from one of leasehold to "almost freehold" (i.e., the market expects that leasehold land will be automatically be renewed without payment of a premium upon the expiry of a lease). Our result shows that there has been an increase in the magnitude of housing bubbles in Hong Kong since 1997, which provides further empirical support to our hypothesis. The results also have important policy implications for developing markets where the land tenure systems are still evolving.
\end{abstract}

Keywords: freehold, housing bubble; land tenure, leasehold, state-space model.

\footnotetext{
${ }^{\mathrm{d}} \mathrm{PhD}$ student, Department of Land Economics, National Chengchi University, Taipei, Taiwan. Tel:+886 -2-29387481,E-Mail:babu0910@gmail.com.

e Professor, Department of Land Economics, National Chengchi University, Taipei, Taiwan. Tel:+886 -2-29387478, e-mail:jachang@nccu.edu.tw.

${ }^{\mathrm{f}}$ Professor, Dept of Real Estate \& Construction, The University of Hong Kong, Hong Kong.
} 


\section{Introduction}

After the recent sub-prime mortgage crisis, the United States initiated a number of quantitative easing policies to rescue its economy. As a result, a large amount of hot money flowed into the Asian housing markets and caused rapid housing price increases from 2008 to 2012 in many Asian metropolitan areas including Taipei, Hong Kong, Beijing, Shanghai, etc. The recent dramatic increase in housing prices in Taipei and Hong Kong (Figure 1. ) have attracted much attention from the media and have been widely perceived to be housing bubbles. Figure 2. shows that transaction volume increased along with housing prices, suggesting that increases in housing prices have not deterred most people's desire to own a home.

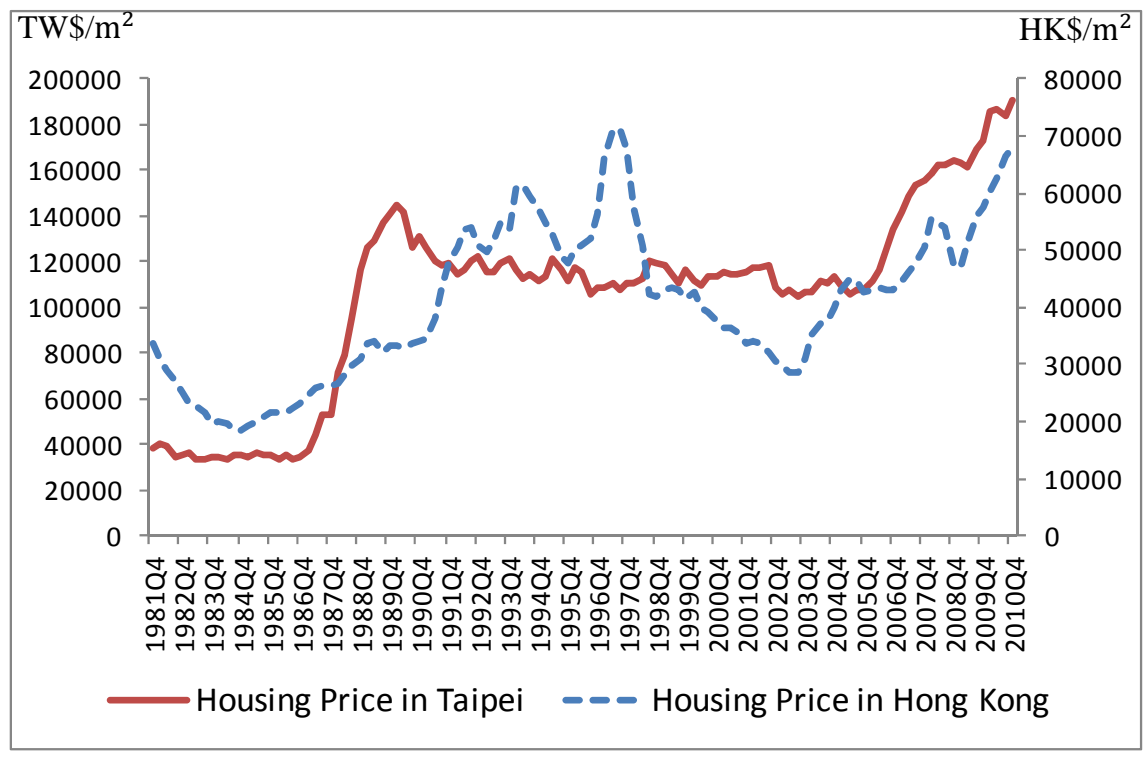

Figure 1. The Trend of Housing Prices in Taipei and Hong Kong

Source: Department of Construction and Planning Administration of the Ministry of Interior Rating and Valuation Department, Hong Kong, http://www.rvd.gov.hk/en/publications/pro-review.htm 


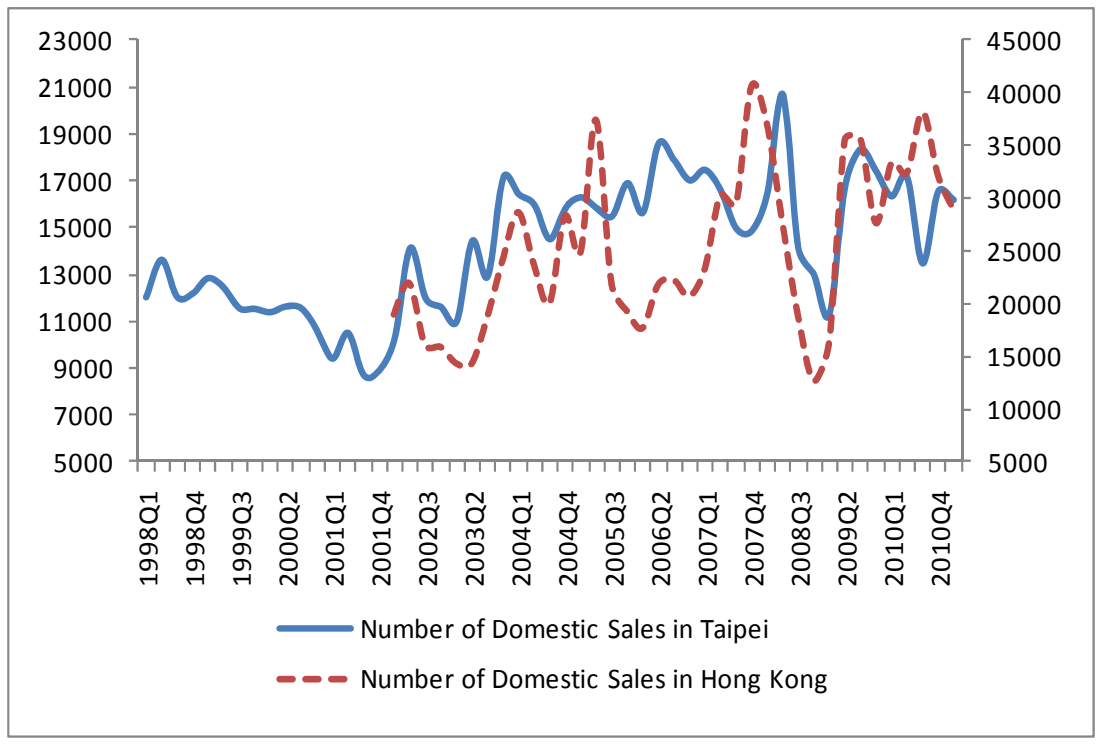

Figure 2. Number of Domestic Sales in Taipei and Hong Kong

Source: Housing Statistic, Taipei, http://housing.cpami.gov.tw/house/default.aspx

Rating and Valuation Department, Hong Kong, http://www.rvd.gov.hk/en/publications/pro-review.htm

There is a Chinese saying that states: "Owning land is the only means to become rich." Hence, the homeownership has the dual motive of consumption (a place to live) and investment (wealth accumulation) with more emphasis on the latter in the Chinese culture. Hulme (1996) described this phenomenon as the "land myth" the preconceived idea that real estate prices could never go down, which encourages people to invest their money in real estate. This may partly explain the observed higher homeownership rate amongst Chinese immigrants in the United State (e.g. Painter et al 2004). The homeownership rate in Taipei stayed at a relatively high level (71.5\% in 2010), while that in Hong Kong was 53.2\% in 2011. Since homeownership is associated with the investment demand for housing in the context of Chinese culture, there seems to be a stronger investment demand for housing in Taipei. Give that investment demand is more likely to cause bubbles; the difference in the homeownership rate between the two cities may hint at the size of housing bubbles in Taipei being larger. However, this casual reasoning hinges on some unobservable characteristics of Chinese culture that cannot be regarded as scientific. In addition, there are also many factors that affect the average homeownership rate beside investment demand, such as government policy and affordability.

In this study, we will attempt to explain how different land tenure systems affect the size of housing bubbles. We define a housing bubble as a deviation in housing prices from its fundamental value determined by the net present value of the expected streams of future rental incomes (or housing services). Capozza and Sick (1991) and 
later Clapp and Salavei (2010) suggested that housing price can be broken down into two components: current use value and the real option value to redevelop. The expected value of this option value increases with an increase in the volatility of housing prices. Therefore, an external shock that increases housing price will also increase housing price volatility will. This will, in turn, increase the expected redevelopment option value, making the housing price sensitive to external shocks. Since a freehold property has a much longer economic life than a leasehold property, its redevelopment option value, as a percentage of its observed market value, is larger than that of a leasehold property. Since real option value to redevelop cannot be negative, tenure choice will affect the size of positive bubbles (positive deviation of market price from fundamental price) only. Therefore average size of positive bubbles is like to be larger in housing markets with freehold land tenure.

The remainder of this paper is organized as follows. Section 2 is the literature review. Section 3 develops the hypothesis. Section 4 describes the method for measuring housing bubbles. Section 5 describes the data in this paper. Section 6 presents the empirical results and Section 7 summarizes the major findings of the paper.

\section{Literature Review}

There are different opinions on the definition of a bubble. Stiglitz (1990) defines it as a current high price resulting from investors' belief that its selling price will be even higher tomorrow even though "fundamental" factors do not justify such a price. Fernández-Kranz and Hon (2006) categorize a bubble according to three aspects. First, a real estate bubble shows an abnormally large trough-to-peak price increase. Second, the asset price in question exceeds its fundamental value by a large margin. Third, a price boom is caused by a transitory demand shock. Another perspective is that the long term equilibrium price is determined by market fundamentals. Thus, a bubble is formed when the market price deviates significantly from the price level justified by market fundamentals (Diba \& Grossman, 1988; Flood \& Hodrick, 1986). In brief, bubbles are formed when there is an over-expectation of future housing price appreciation, which cause prices to deviate significantly from that justified by market

fundamentals. However, what constitutes market fundamentals and how they determine fundamental price varies across different. Empirically, it is also difficult differentiate the deviation caused by bubbles and the noise in the data.

Empirical research on price bubbles often relies on analysis of asset price movement over time (Stiglitz, 1990). Following the definition by Blanchard and Fisher (1989), asset price is composed of a fundamental price and a bubble price. 
Many studies have focused on developing models to estimate the fundamental price, so as to verify the existence of a bubble. Therefore, to show the existence of a bubble in the housing market, the first step is to estimate the fundamental price.

Quigley (1999) considers that in a competitive housing market, prices are determined by housing supply and demand. Therefore, fundamentals are composed of supply and demand factors that can be measured by macroeconomic variables (Hui \& Shen, 2006; Shen, Hui, \& Liu, 2005). The existence of a price bubble can be interpreted as a deviation of prices from the fundamental price implied by the relationship between real estate prices and supply and demand side macroeconomic variables. If the observed price is in line with that predicted by demand and supply variables, a bubble does not exist. Abraham and Hendershott (1996) and Bourassa et al. (2001) followed Capozza and Helsley's (1989) approach to model fundamental real housing prices with macroeconomic variables to test the existence of housing bubbles. However, modeling fundamental prices from macroeconomic variables is itself problematic and subject to specification error. Any identified bubbles could simply be due to model misspecification.

One way to estimate fundamental housing prices is to model the consumption demand for housing. Housing consumption demand is best reflected in rental levels. Since rental data may not be readily available even in many developed countries, disposable income is used instead. This approach considers income as the major demand driver for housing services. The price-to-income ratio should stay within an affordable range (Black, Fraser, \& Hoesli, 2006; Fernández-Kranz \& Hon, 2006), outside which is considered as price bubble. Black et al. (2006) developed an innovative way of estimating the fundamental price of housing in the UK based on the assumption of constant ratio between real housing value and present value of real disposable income. Given that this ratio is constant, disposable income can be used to replace rental income in estimating the fundamental housing prices. However, housing price to disposal income ratio can vary substantially over time due to policy change. Black et al's method of using disposable income instead of rent was mainly unavailability of rental data in the $\mathrm{UK}^{1}$.

Many studies have modeled fundamental prices using the rent and discount rate. This approach models the asset price as the sum of the expected future rent, discounted at a constant rate of return (Bjorklund \& Soderberg, 1999; Chan et al., 2001; Hamilton, 1985; Hatzvi \& Otto, 2008; Smith et al, 2006; Xiao \& Tan, 2007). Instead of identifying bubbles with models that estimate fundamental prices from

\footnotetext{
${ }^{1}$ See footnote 3 of Black et al (2006).
} 
historical prices and other macroeconomic variables, this approach views deviation of prices from discounted expected future rents as a bubble. Smith et al. (2006) define a "bubble as a situation in which the market prices of certain assets (such as stocks or real estate) rise far above the present value of the anticipated cash flow from the asset". The advantage of this approach is that it does not need a lot of data. However the result of this approach is sensitive to the method of estimating the expected future rental growth and discount rate.

Deviation of market price from fundamental price can be positive or negative. The term "negative bubble" has been used Shiller (2003) and Siegel (2003) to describe the latter case. The distinction of positive bubble from negative bubble is important for this study since the real redevelopment option only affect the magnitude of positive bubbles.

Bubble tests are hard to design, since the path of a bubble in the data would look like some forms of error in modeling of agents' expectations (Flood \& Hodrick, 1986). The variance bounds test is one of the convenient methods for testing the existence of bubbles. However, Flood and Hodrick (1986) argue that the failure of some variance bounds tests should not be taken as evidence of rational speculative bubbles, as the results are sensitive to the design of the tests. Another approach is to benchmark housing prices against equilibrium prices predicted by economic models (Case \& Shiller, 2003; Hui \& Shen, 2006; Smith et al., 2006). Again, the problem of this approach is that the economic models are assumed to be correctly specified.

Wu (1997) estimates the rational bubble in the stock market, which can collapse and restart continuously using a state-space model. This model overcomes the problem of unstable intrinsic bubble specification proposed by Froot \& Obstfeld (1991), which implies that the bubble will never burst as long as dividend remains positive. In Wu's paper, a bubble is treated as an unobserved state variable that can be estimated by the Kalman filter. He shows that many of the deviations of stock prices from the present-value model are captured as bubbles in his model. Recent studies have used an improved state-space model to test for the existence of bubbles (Alessandri, 2006; Blyth, 2008; Xiao \& Tan, 2007). There are, however, very few empirical studies that have applied the state-space model to compare the magnitude of housing bubbles in different cities.

There are a number of empirical studies that have examined housing bubbles in Taipei or Hong Kong. Chan et al. (2001) examine the existence of unobservable misspecification errors and rational bubbles in the housing markets of three urban regions in Hong Kong. They show that the bubbles exploded most sharply between 
1990 and 1992 and between 1995 and 1997. Xiao and Tan (2007) use the Kalman filter to investigate the large swings in property prices in Hong Kong during the 1980s and 1990s due to the collapse of rational speculative bubbles. Moreover, Xiao and Tan suggest that restrictions in supply are some of the key causes of speculative bubbles in the real estate market. Chang, et al. (2009) applies the state-space model to show that bubble prices are significant in 2008 in the Taipei housing market. Tsai and Peng (2011) show that the bubble-like behavior of house prices in Taiwan before 1998 can be explained by the investment demands of the housing market, but after 1999, the cause was due more to mortgage rates. These studies suggest that the bubbles in Taipei and Hong Kong's housing markets were mainly caused by excessive investment demand for housing fuelled by financial market factors such as money supply, interest rates, and stock market sentiments.

Previous studies mainly focus on testing the existence of housing bubbles. Some also attempted to explain them. However, there has been no study on the impact of different land tenure system on the size of housing bubbles thus far. This study fills this gap by examining the housing bubbles in Taipei and Hong Kong.

\section{Development of the hypothesis}

Empirical observations in Canada (Capozza, \& Sick 1991), Singapore, and Hong Kong (Tu and Bao, 2009) suggested that a freehold property is approximately $30 \%$ more expensive than a long leasehold property after acoounting for the differences in the stream of rental income beyond the leasehold period. Copazza and Sick (1991) suggestthat this difference is due to the value of the redevelopment real option embbeded in freehold properties.

A real option is analogous to a financial option. A financial option is a contract between a buyer and a seller for a predefined future transaction on an underlying asset at a reference price (the exercise price) within a certain pre-specified time period (before the expiry date of the option contract). The buyer of the option has the right, but not the obligation, to complete the future transaction. Because of this right without obligation (i.e., option) to the buyer, he/she has to pay the seller a premium such that at any time, $\boldsymbol{t}$, before the expiry date, the sum of the option price and the exercise price is larger than the spot price of the underlying asset at time $\boldsymbol{t}$. The premium (option value) will diminish over time and eventually vanish after the expiry date.

Similar to a financial option, a real option is the right, but not the obligation, to undertake certain business initiatives when the opportunity arises, such as redeveloping a property for the same or different uses (with a higher market value) 
when the value of the redeveloped property has substantially exceeded that of its current use. These rights without obligations to redevelop are referred to as "real option" because the underlying assets are tangible assets rather than financial instruments. Unlike financial options, the redevelopment real option in a freehold property can be "exercised" an unlimited number of times and there is no expiry date.

Depending on the remaining lease period, the redevelopment option value to the leasehold property owner is usually a lot smaller for a number of reasons. First, such an opportunity may not arise during the lease period. Second, redevelopment involves a huge capital investment. If the remaining lease period is not long enough, the leasehold property owner will not be able to exploit the full benefit of redevelopment even if a better alternative use would generate higher rental income in the long run. Third, the redevelop option can only be exercised a limited number of times during the lease period.

When the market is bullish, expected re-development potential will also increase, which will in turn increase the redevelopment option value. This could drive housing price to level well above fundamental level. Furthermore, similar to financial options, the real option value also depends on the uncertainty of the market prices of the underlying financial asset, which can be measured by the observed price volatility. That is, the redevelopment option value depends on the volatility of the price of the redeveloped property. In the context of the housing market, the redeveloped property would normally be a housing unit with a newer and better design and more facilities. At the beginning of the formation of a housing bubble, an initial small increase in housing prices beyond that is justified by market fundamentals would, at the same time, increase housing price volatility, which will, in turn, increase the redevelopment option value, which lead to further increases in housing prices. This will, again, further increase housing price volatility and, thus, result in a positive feedback that drives housing prices further away from their fundamental prices. $^{2}$ This positive feedback process is different from the bubble formation feedback model described in Shiller (2003), which relies on irrational behavior that has recently found supports in cognitive psychology and experimental economics. The positive feedback process describe above is purely resulted from the positive relationship between real option value and the price volatility of the underlying asset, which does not rely on irrational behavior. However, our aim is not to reject the behavioral aspect of the price formation process that leads to housing bubbles. Rather, we suggest that in addition to the bubble formation and burst cycle

\footnotetext{
${ }^{2}$ This also explains the findings in Davis and Heathcote (2007), which stated that the prices of vacant plots of land (with no current use value) are more volatile than those of housing, since vacant land has little or no use value.
} 
predicted by the feedback theory, the presence of real redevelopment option value in housing prices has an independent and additional effect that the further propels the housing bubble.

When the housing bubble bursts, not only that the value of the real option to redevelop diminished, the bearish sentiment will drive housing price below the value justified by market fundamentals, as predicted by the feedback model, resulting in a negative housing bubble (as described by Shiller and Siegel (2003), which carries the seed for future price increase and subsequent formation of another housing bubble.

While the feedback theory can lead to both positive and negative bubbles (Shiller, 2003), the bubble caused by changes in expected real redevelopment option value can only lead to positive bubbles. As a consequence of the additional positive feedback arising from the positive relationship between volatility and value of real redevelopment option, the magnitude of positive housing bubbles will be larger if the redevelopment option value constitutes a higher proportion of the housing value, as in the case of freehold properties.

Therefore, we propose the following hypothesis:

The magnitude of positive housing bubbles in housing markets dominated by the freehold land tenure system is larger than those in markets dominated by the leasehold land tenure system, ceteris paribus.

This hypothesis will be tested with data from Taipei (freehold land tenure system) and Hong Kong (leasehold land tenure system).

\section{Empirical Model}

There are three problems in estimating the magnitude of housing bubbles. First, we need to measure fundamental housing price. Second, since the observed housing price levels are never measured without error, the observed difference between housing market price and fundamental housing price cannot be entirely attributed to housing bubble price. Third, housing bubbles are not directly observable.

To solve these problems, we adopt Alessandri's (2006) state-space model to estimate the size of housing bubbles. Following Alessandri's (2006) approach of using dividends to capture market fundamentals in the stock market, we use rent to capture market fundamentals in the housing market. Assuming that the risk premium of investing in housing is constant, the expected total return on housing is $\left(E_{t} P_{t+1}-P_{t}\right) / P_{t}+D_{t} / P_{t}=r_{t}+\alpha$, where $P_{t}$ is housing price, $D_{t}$ is housing rent, $E_{t} P_{t+l}$ is the expected price one period ahead, $r_{t}$ is the risk-free rate, and $\alpha$ is the risk 
premium. The forward solution for fundamental price is $P_{t}^{f}=\sum_{i=0}^{\infty}\left[\prod_{j=0}^{i}\left(1+r_{t+j}+\alpha\right)^{-1}\right] D_{t+i}$.

Assuming that the risk-free rate has a finite unconditional mean, $E\left(r_{t}\right) \equiv r$ the long term "average" discount factor can be defined as $\beta \equiv(1+r+\alpha)^{-1}$. The first-order Taylor approximation of $P_{t}^{f}$ around $r$ gives $P_{t}^{f} \cong P_{t}^{L}+R_{t}$, where $P_{t}^{L}$ and $R_{t}$ are defined as:

$$
\begin{aligned}
& P_{t}^{L} \equiv \sum_{i=0}^{\infty} \beta^{i+1} E_{t} D_{t+i} \\
& R_{t} \equiv-\sum_{i=0}^{\infty}\left\{\left[\beta^{i+1} \sum_{k=0}^{\infty} \beta^{k+1} E_{t} D_{t+i+k}\right]\left(E_{t} r_{t+i}-r\right)\right\}
\end{aligned}
$$

We assume that rent is expected to grow at a positive constant rate so that $D_{t}=\phi D_{t-1}+\varepsilon$, where $\phi>1$ and the risk-free rate follows a first-order autoregressive process such that $r_{t}=\rho_{0}+\rho_{1} r_{t-1}+\eta_{t}$, where $\varepsilon_{t}$ and $\eta_{t}$ are zero-mean, serially-uncorrelated error terms. Sufficient conditions for the series of conditional expectations in $P_{t}^{L}$ and $R_{t}$ to be defined are $\beta \phi<1$ and $\left|\rho_{1}\right|<1$. The expected future rent $\boldsymbol{i}$ period ahead is $E_{t} D_{t+i}=\phi^{i} D_{t}$, the expected long term mean risk-free rate is $r=\rho_{0} /\left(1+\rho_{1}\right)$, and the expected risk-free rate $\boldsymbol{i}$ period ahead is $E_{t}\left(r_{t+i}-r\right)=\rho_{1}^{i}\left(r_{t}-r\right)$, which simplifies Equations (1) and (2) respectively to:

$$
\begin{aligned}
& P_{t}^{L}=\frac{\beta}{1-\beta \phi} D_{t} \\
& R_{t}=\left(\frac{\rho_{0}}{1-\rho_{1}} \frac{\beta^{2}}{1-\beta \phi} \frac{1}{1-\beta \phi \rho_{1}}\right) D_{t}-\left(\frac{\beta^{2}}{1-\beta \phi} \frac{1}{1-\beta \phi \rho_{1}}\right) D_{t} r_{t}
\end{aligned}
$$

The fundamental price, $P_{t}^{f} \cong P_{t}^{L}+R_{t}$, is thus given as:

$$
P_{t}^{f} \cong \frac{\beta}{1-\beta \phi}\left(1+\frac{\rho_{0}}{1-\rho_{1}} \frac{\beta}{1-\beta \phi \rho_{1}}\right) D_{t}-\left(\frac{\beta^{2}}{(1-\beta \phi)\left(1-\beta \phi \rho_{1}\right)}\right) D_{t} r_{t} \equiv c_{0} D_{t}+c_{1} D_{t} r_{t}
$$

At any point in time, the bubble price $\left(\boldsymbol{B}_{t}\right)$ (if it exists) is defined as deviation of the 
market price form the fundamental price such that $P_{t}=P_{t}^{f}+B_{t}+\xi_{t}$ where $\xi_{t}$ is a zero-mean, serially-uncorrelated error term. Following Alessandri, $\boldsymbol{B}_{\boldsymbol{t}}$ is driven by the risk free interest rate in the previous period in a manner that can be described by the following time varying $\mathrm{AR}(1)$ process

$$
B_{t+1}=\left(1+r_{t}+\alpha\right) B_{t}+b_{t+1}
$$

where $\boldsymbol{b}_{\boldsymbol{t}+\mathbf{1}}$ is a zero-mean, serially-uncorrelated error term.

This specification allows the bubble price to grows (or shrink) at time varying rates determined by the bubble price and risk-free rate in the previous period. The sign of $\boldsymbol{B}_{\boldsymbol{t}}$ need not be positive meaning that market price can be higher or lower than the fundamental price.

Based on equation (5), the market price at time $\boldsymbol{t}$ can be written as

$$
P_{t}=C_{0} D_{t}+C_{1} D_{t} r_{t}+B_{t}+\xi_{t}
$$

where $\xi_{t}$ is a zero-mean, serially-uncorrelated error term.

Since the $\boldsymbol{P}_{\boldsymbol{t}}$ has an unobservable component, $\boldsymbol{B}_{\boldsymbol{t}}$, the standard regression procedures cannot be used to estimate the parameters of equation (7). Estimation of equation (7) (also known as the observation or measurement equation) must take into account of the dynamics of the unobservable variable (or state variable) represented by equation (6), which is also known as the state equation. Equation (6), (7) and the AR(1) processes of $\boldsymbol{D}$ and $\boldsymbol{r}$ together constitute a state-space model. In general, a state space model is a time series model that includes one or more unobservable variables (state variables), the dynamics of which can be represented by a state equation. The parameters of the observation equation and state equation can be estimated jointly using maximum likelihood methods. The state space model also allows us to separate the deviation of the observed market price from the fundamental price into measurement error $\left(\xi_{t}\right)$ generated by a white noise process and the bubble price $\left(\boldsymbol{B}_{t}\right)$, the evolution of which is driven by lagged bubble price and interest rate.

\section{Empirical Data}

We use data from Taipei and Hong Kong to test our hypothesis. Taipei is the capital of Taiwan as well as its political, economic, and cultural center. Hong Kong is one of two Special Administrative Regions (SARs) of the People's Republic of China (PRC) and one of the world's leading international financial centres. Its land tenure system is predominately leasehold. The government owns all the land in Hong Kong. With the exception of some plots of land on Hong Kong Island that have 999-year lease periods (Wong et al., 2008), which is close to freehold, most land 
plots were initially granted for a period of less than 75 years. The two cities are approximately $800 \mathrm{~km}$ apart with a flight time in either direction of approximately 45 minutes (Figure 3).

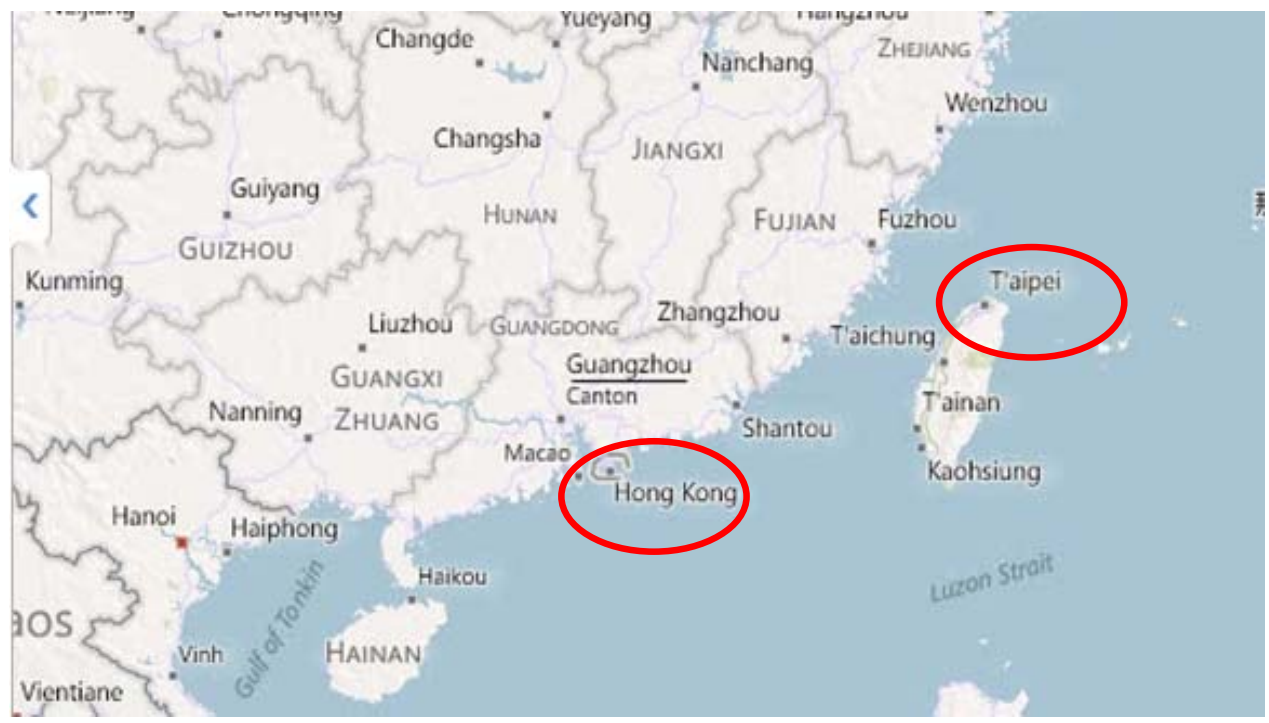

Figure 3. The geographical relationship between Taipei and Hong Kong Source: http://www.bing.com/maps/

Both Taipei and Hong Kong are densely populated cities with a majority of their populations being ethical Chinese. Both cities have the problem of land shortage. The total land area of Taipei is $272 \mathrm{~km}^{2}$. Its population was 2,618,772 at the end of 2010. Hong Kong has a total land area of $1,108 \mathrm{~km}^{2}$, but $80 \%$ of the territory are considered too hilly for property development (Chan, Lee, \& Woo, 2001). More importantly, only about $7 \%\left(76 \mathrm{~km}^{2}\right)$ of the land in Hong Kong are zoned for residential use $\mathrm{e}^{3}$, some of which have not been developed. In other words, Hong Kong has only used less than $76 \mathrm{~km}^{2}$ of its land to house a population of 7,097,600, making it one of the most densely populated cities in the world. As at the end of 2010, the estimated the total number of households in Taipei and Hong Kong are 980,000 and 2,350,000, respectively.

Both Taiwan and Hong Kong are considered to be developed economies in Asia. As of the end of 2010, the per capita gross domestic products (GDP) of Taiwan and Hong Kong were US\$18,588 and US\$31,693, respectively. Both economies depend significantly on the performance of the US economy. The Hong Kong Dollar has been pegged to the US Dollar since October 1983, which effectively equates all HKD to USD at an exchange rate of HK\$7.8 to US\$1. This currency board system has forced the Hong Kong monetary policy to follow that of the US (Chau, 1997).

\footnotetext{
${ }^{3}$ http://www.pland.gov.hk/pland_en/info_serv/statistic/landu.html.
} 
Although Taiwan has adopted a free exchange rate policy since 1989, the exchange rate of the New Taiwan Dollar is still largely dependent on the USD. Even after 1989, Kawai (2008) found that on average, more than $90 \%$ of the daily change in the New Taiwan Dollar's can be explained by the those of the USD from 1990 to 2006.

However, the economic bases of Taipei and Hong Kong are very different. Taipei has always led Taiwan's economic development and has now become one of the world's foremost cities in the production of high technology components. ${ }^{4}$ This is part of the so-called "Taiwan Miracle," which has seen dramatic economic growth following substantial foreign direct investment during the 1960s. Taiwan is now a creditor economy, holding one of the largest foreign exchange reserves of over US\$394.4 billion as of February 2011. ${ }^{5}$ On the other hand, Hong Kong is a service sector-led economy characterized by low taxation and free trade. ${ }^{6}$ The Hong Kong Dollar is the eighth most-traded currency in the world as of 2010. ${ }^{7}$ Furthermore, Hong Kong is also an important hub for international financial and trading services, with one of the greatest concentrations of corporate headquarters in the Asia-Pacific region. ${ }^{8}$

The state of economic development, the dependence on exports, strong ties of their currencies to the USD, and dense populations of Hong Kong and Taipei make housing prices in these two cities susceptible to external shocks, particularly from changes in the US economy, which may lead to the formation of bubbles. It is likely that the housing bubbles in these two markets share the same set of underlying root causes, and yet, these two markets have very different land tenure systems, which make them ideal for testing our hypothesis.

Quarterly housing price data from Taipei and Hong Kong are available from 1981Q2 through 2010Q4. This study use the average unit prices of first hand sales (including sale of uncompleted and completed units by developers) in the Taipei area obtained from the Taiwan Real Estate Research Center, National Cheng-Chi University. This housing price data series is the longest consistent data series with the widest coverable amongst all housing price data series available in Taipei. Although recently real estate agents have developed housing price indices based on secondary market

\footnotetext{
${ }^{4}$ Kwok, R.Y.W. (2005). Globalizing Taipei: the political economy of spatial development.

5 "National Statistics, Republic of China - Latest Indicators". Directorate General of Budget, Accounting and Statistics. http://eng.stat.gov.tw/point.asp?index=5.

${ }^{6}$ Yiu (2008) described the Hong Kong Government's economic policy as a free market policy with few attempts by the government to influence prices in the resource and product market.

7 "Triennial Central Bank Survey: Report on global foreign exchange market activity in 2010". Monetary and Economic Department (Bank for International Settlements): 12. December 2010. http://www.bis.org/publ/rpfxf10t.pdf. Retrieved 15 October 2011.

${ }_{8}^{8}$ Bromma, H. (2007). How to Invest in Offshore Real Estate and Pay Little Or No Taxes. McGraw-Hill Professional. p. 161.
} 
transactions, the data series are short (the longest one only dates back to 1998Q1). More importantly, they are based on transaction handled by respective real estate agent only. The sample is typically small $(<5 \%)$ and unlikely to be representative (Chang et al, 2008). Data for rent were downloaded from the Taipei online enquiry system for statistical data. ${ }^{9}$ The prime rate (or base lending rate) offered by major banks in Taiwan is used as a proxy for risk-free rate. ${ }^{10}$

Quarterly housing price and rental data for Hong Kong were downloaded from the Hong Kong Rating and Valuation Department (RVD) Website. ${ }^{11}$ The RVD is the only source of rental price series. The housing price data series from RVD are the longest data series amongst all the available housing price data series in Hong Kong (Chau et al, 2005). As a result of Hong Kong's pegged exchange rate system implemented in October 1983, US interest rates have been commonly used as for Hong Kong interest rates (Chau, 1997). However, before October 1984, US interest rates cannot be used as proxy for Hong Kong interest rates. Even after the implementation of the pegged exchange system, there were certain periods in Hong Kong when the pegged exchange rate were under attack (e.g. in 1998 after the Asian financial crisis), which make Hong Kong interest rates deviates substantially from US interest rates. Instead of using US risk free rate, we have used prime rate (best lending rate offered by HSBC and other major banks in Hong Kong) for this study. The use of prime rate for both cities also makes comparison between the two markets more reliable. Tables 1 and 2 report the descriptive statistics of data for the two cities.

Table 1. Descriptive Statistics of Variables in Taipei, 1981Q1 to 2010Q4

\begin{tabular}{lcccc}
\hline Variables & Mean & Standard deviation & Skew & Kurt \\
\hline Housing Price $\left(\mathrm{TW} \$ \mathrm{~m}^{2}\right)$ & 103,843 & 41,732 & -0.397 & 2.473 \\
Rent price $\left(\mathrm{TW} \$ \mathrm{~m}^{2} / \mathrm{month}\right)$ & 222.70 & 15.92 & 0.033 & 1.580 \\
Interest Rate $(\%)$ & 6.10 & 3.468 & 0.613 & 2.842 \\
\hline
\end{tabular}

Table 2. Descriptive Statistics of Variables in Hong Kong, 1981Q1 to 2010Q4

\begin{tabular}{lcccc}
\hline Variables & Mean & Standard deviation & Skew & Kurt \\
\hline Housing Price $\left(\mathrm{HK} \$ / \mathrm{m}^{2}\right)$ & 40,543 & 13,313 & 0.238 & 2.261 \\
Rent price $\left(\mathrm{HK} \$ / \mathrm{m}^{2} /\right.$ month) & 183.92 & 28.090 & 0.092 & 1.852 \\
Interest Rate $(\%)$ & 8.36 & 2.981 & 1.235 & 4.625 \\
\hline
\end{tabular}

\footnotetext{
${ }^{9}$ http://163.29.37.101/pxweb2007-tp/dialog/statfile9.asp.

10 http://www.cbc.gov.tw/mp1.html.

11 http://www.rvd.gov.hk/tc/publications/pro-review.htm.
} 


\section{Results and interpretation}

The results of estimating the state-space model for Taipei are shown in Table 3. All coefficients are significant at the $1 \%$ level. The sign of $c_{l}$ is negative, which confirms the negative relationship between interest rates and housing prices when rental level remains unchanged. The estimated risk premium $\gamma$ is close to zero, which suggests that the average risk premium of investing in housing is similar to the premium of the prime rate above the risk free rate.

Table 3. Estimated Housing Price State-Space Model in Taipei

\begin{tabular}{|c|c|c|c|}
\hline \multicolumn{2}{|c|}{$P_{t}=c_{0} D_{t}+c_{1} D_{t} r_{t}+B_{t}+\varepsilon_{t}$} & \multicolumn{2}{|c|}{$B_{t}=\left(1+r_{t-1}+\gamma\right) B_{t-1}+b_{t}$} \\
\hline & $c_{0}$ & $c_{1}$ & $\gamma$ \\
\hline Coefficient & $678.5^{* * *}$ & $-41,313.4^{* * *}$ & $-1.74 \times 10^{-10_{* * *}}$ \\
\hline Standard error & $8.67 \times 10^{-7}$ & $1.41 \times 10^{-5}$ & $4.72 \times 10^{-11}$ \\
\hline
\end{tabular}

*** Significant at the $1 \%$ level

Figure 4. shows the trend of the housing price and bubble price deduced from the state-space model. The result shows that bubble prices are at their highest around 1990 and 2010. There are also periods (particularly during the early 1980s) with negative bubble prices, which indicate that these periods are dominated by overly pessimistic sentiment. This could be due to the fact that the Taiwanese financial market was less open during the 1980s. After the relaxation of a number of financial market regulatory controls, more international hot money found its way into the Taiwanese financial market, which fuelled asset prices, including housing prices.

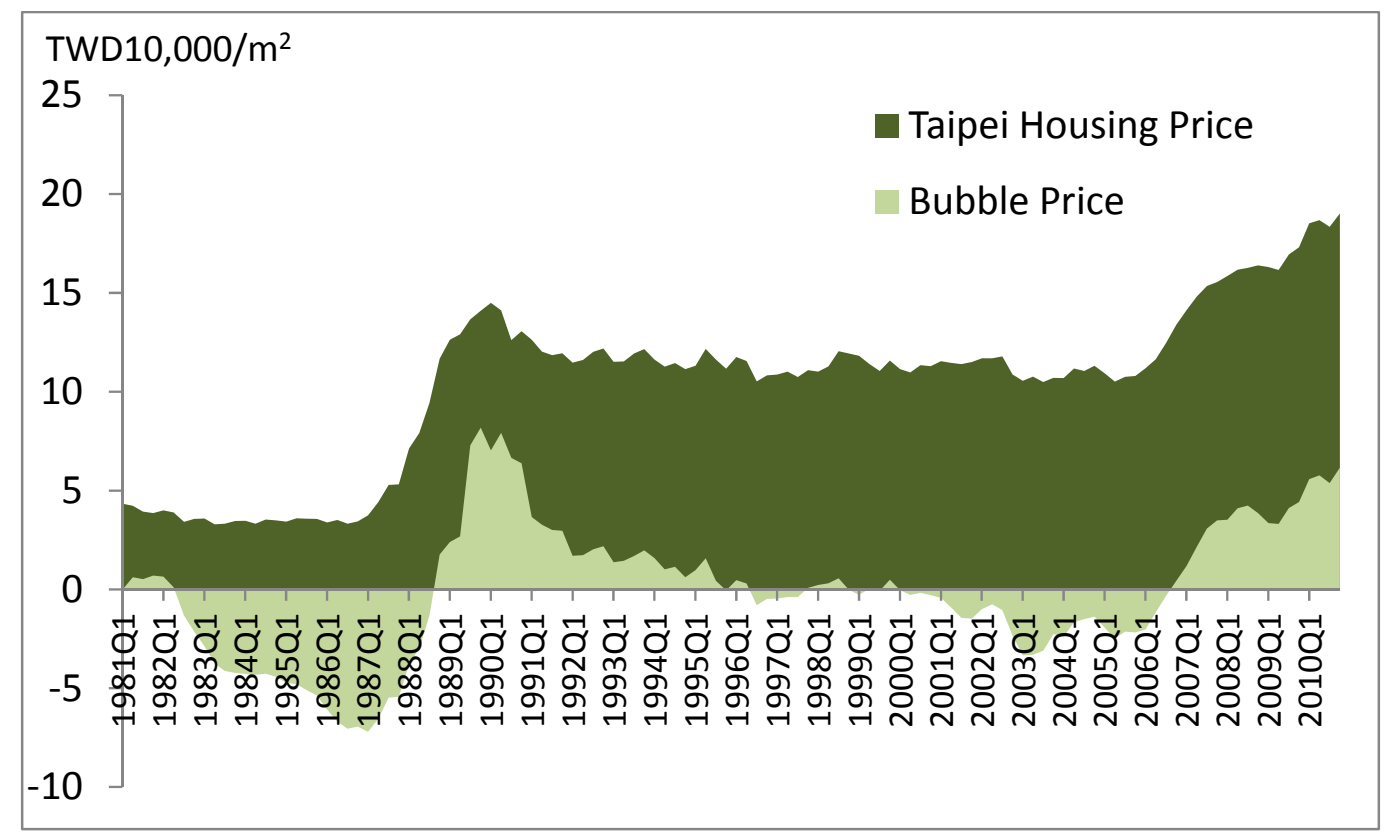

Figure 4. Trends of Housing Price and Bubble Price in Taipei 
The results of estimating the state-space model for Hong Kong are shown in Table 4. All coefficients are significant at the $1 \%$ level and of the same sign as those in the Taipei model.

Table 4. Estimated Housing Price State-Space Model in Hong Kong

\begin{tabular}{|c|c|c|c|}
\hline \multicolumn{2}{|c|}{$P_{t}=c_{0} D_{t}+c_{1} D_{t} r_{t}+B_{t}+\varepsilon_{t}$} & \multicolumn{2}{|c|}{$B_{t}=\left(1+r_{t-1}+\gamma\right) B_{t-1}+b_{t}$} \\
\hline & $c_{0}$ & $c_{1}$ & $\gamma$ \\
\hline Coefficient & $333.0 * * *$ & $-15,619.6^{* * *}$ & $-0.11 \times 10^{-4} * * *$ \\
\hline Standard error & $8.91 \times 10^{-6}$ & $3.65 \times 10^{-4}$ & $5.34 \times 10^{-9}$ \\
\hline
\end{tabular}

*** Significant at the $1 \%$ level

Figure 5. shows the bubble price in the Hong Kong housing market estimated from the state-space model. Similar to Taipei, there was a negative housing bubble during the 1980s. The reason for the bearish sentiment during this period is most likely due to the political uncertainty about the future of Hong Kong (Chau, 1997). As more detailed information about Hong Kong's future were revealed to the public, the market regained confidence. During the 1990s, Hong Kong's economy benefited from fast economic growth in China, which started to fuel housing price. Due to its pegged exchange policy, Hong Kong could not increase interest rates to tighten the money supply, which resulted in a prolonged period of negative real interest rates during the 1990s. All these factors contributed to the exceedingly bullish sentiment before the handover in 1997. Eventually, the Asian Financial Crisis acted as a catalyst that led to the bursting of the housing bubble.

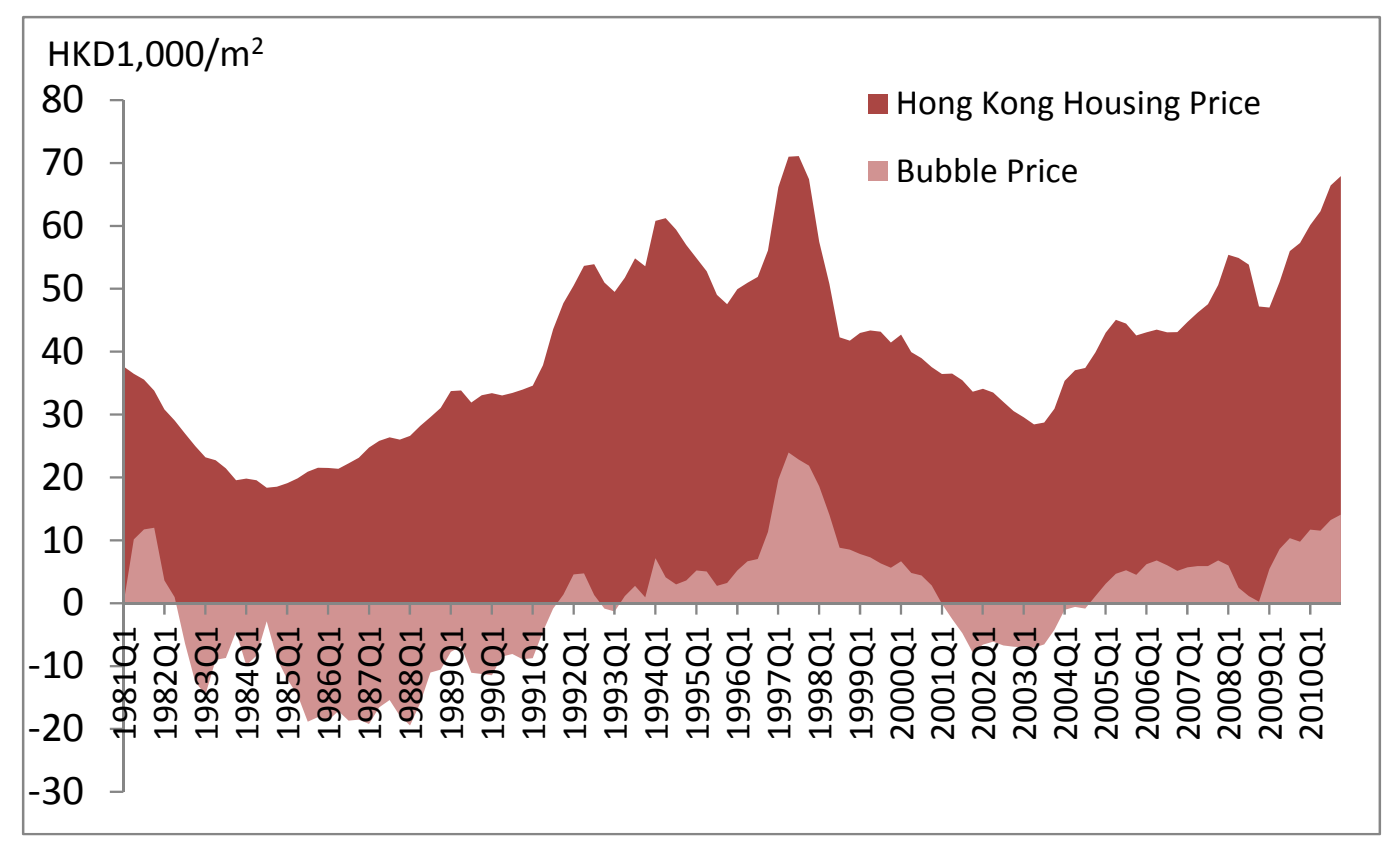

Figure 5. Trends of Housing Price and Bubble Price in Hong Kong 
Although the correlation between returns on housing prices in Hong Kong and Taipei is close to zero ( $r=0.098)$, there is a strong correlation between the bubble prices (as percentage of total price) in the two cities $(r=0.756)$. This may imply that while housing prices in Hong Kong and Taipei are driven by different market fundamentals, the two markets may share some factors that caused housing bubbles. ${ }^{12}$

Table 5 shows the average size of the positive bubbles (bubble price as a percentag of market price) in the two cities. We ignore the periods when the bubble prices are equal or less than zero and focus on the positive bubbles which the real option to redevelop played important role. During the entire period of observation, the average positive bubble price in Taipei is higher, which is consistent with our hypothesis. However, what is also revealing is that the average positive bubble price in Hong Kong became bigger after 1997Q2. After 15 July 1997, the Hong Kong Government implemented a policy of automatically renewing land leases after they expire without leaseholders having to pay a premium. Although this is only a policy with no legal status and the renewal without premium is at the government's sole discretion, after many incidents of automatic renewals without premiums (16 cases so far), the market has slowly built up confidence that the policy will continue in the future. Hence, it is now politically difficult for the government to terminate this policy in the future. The consequence of such a policy is that Hong Kong's housing market now values housing units as if they were leasehold properties with no expriy date (or a expiry period much longer than that in the land lease). This policy has injected a redevelopment option value into Hong Kong's housing prices. As predicted by our hypothesis, this policy would inflate the postive housing bubble in Hong Kong.

The empirical result have policy implications for many developing countries where the systems of land ownerhsip are still evolving. Much research on land tenure systems in developing countries has been methods of improving land security. Both freehold and leasehold are regarded as formal tenure system (De Souza, 1998) that can provide better land security than other informal systems. While formal land tenure system is widely regarded a better institution than informal land ownership (e.g. Calderón, 2004; Khemroa \& Payne, 2004; Porio \& Crisol, 2004), the distinction between freehold and leasehold is less clear. For example, advocates of the freehold

\footnotetext{
${ }^{12}$ While the purpose of this paper was not to investigate the common causes of housing bubbles in Taipei and Hong Kong, we found that bubble prices in both cities were both significantly correlated with the 30-Year US Treasury Note yield ( $r=0.48$ and 0.56 , respectively). However, there was no significant contemporaneous correlation between the 30-Year US Treasury Note yield and housing returns in the two cities.
} 
ownership suggest that it can "reduce bureaucracy and corruption involved in transactions" (Sivam et al, 2001), while proponents of the leashold system argue that it facilitates physical urban planning and that freehold properties are major obstacles to urban land development (Olima \& Obala, 1999). The result of this study provides another dimension, i.e. potential scale of bubbles, for consideration by policy makers in formulating land tenure policy.

Table 5 Average Size of the Positive Bubble (as a percentage of price)

\begin{tabular}{lcc}
\hline & Taipei & Hong Kong \\
\hline 1981Q1- 2010Q4 & $20.1 \%$ & $14.1 \%$ \\
1981Q1- 1997Q2 & $21.0 \%$ & $12.6 \%$ \\
1997Q3- 2010Q4 & $17.2 \%$ & $15.1 \%$ \\
\hline
\end{tabular}

\section{Conclusion}

Our empirical results show that housing prices were traded a below fundamental price (negative housing bubbles) most of the time during the 1980s in both Taipei and Hong Kong. Positive housing bubbles appeared during the 1990s and reappeared after the US implemented its quantitative easing monetary policy in 2009. Besides identifying housing bubbles, we have gone a step further by examining how differences in the land tenure system has affected the size of the positive housing bubbles. Based on Capozza \& Sick's (1991) theory of real redevelopment option in housing prices, we conjecture that bubble size in housing markets with freehold land ownerhsip is larger than those with leasehold land ownerhsip. We use a space-state model to estimate the size of the housing bubbles in Taipei (freehold land) and Hong Kong (leasehold land) from 1981Q1 to 2010Q4. The results show that during the observation period, bubble size was, on average, larger in Tapei, which is consistent with our hypothesis. In addition, there was a major change in land policy after July 1997 in Hong Kong, which effectively extended the expiry dates of all leasehold lands (most of which had initial lease periods of 50 years). Under this policy, land leases will be automatically renewed without the need to pay any land premium (which was not the case before July 1997). Our hypothesis perdicts that such a change would lead to larger housing bubbles, which is also supported by our emprical results. Therefore, this land policy has led to the unintended consequence of increasing the volatility of housing prices in Hong Kong. If the current housing bubble bursts, it is likley to experience a steeper decline in housing prices than those observed before.

The method of estimating bubble prices in this study can also be used to monitor the health of a housing market and assisst policymakers in making more informed decisions. Incidentally, we found that housing returns in the two cities are not 
correlated, while bubble prices are, which indicate the possibility of housing bubbles in the two cities being caused by a set of common factors. This may point to some potentially fruitful areas for further study. The results in this paper also provoide a new dimension, i.e. size of housing bubbles under freehold and leasehold systems, for consideration by policy makers in formualting land tenure policy in developing markets. 


\section{References}

Abraham, J.M., \& Hendershott, P.H. (1996). Bubbles in metropolitan housing markets. Journal of Housing Research, 7(2), 191.

Alessandri, P. (2006). Bubbles and fads in the stock market: another look at the experience of the US. International Journal of Finance \& Economics, 11(3), 195-203.

Bjorklund, K., \& Soderberg, B. (1999). Property cycles, speculative bubbles and the gross income multiplier. The Journal of Real Estate Research, 18(1), 151.

Black, A., Fraser, P., \& Hoesli, M. (2006). House Prices, Fundamentals and Bubbles. Journal of Business Finance \& Accounting, 33(9-10), 1535-1555.

Blyth, M. (2008). The Politics of Compounding Bubbles: The Global Housing Bubble in Comparative Perspective. Comparative European Politics, 6(3), 387.

Bourassa, S.C., Hendershott, P.H., \& Murphy, J. (2001). Further evidence on the existence of housing market bubbles. Journal of Property Research, 18(1), 1.

Bromma, H. (2007). How to Invest in Offshore Real Estate and Pay Little Or No Taxes: McGraw-Hill Professional.

Calderón, J. (2004) The formalisation of property in Peru 2001-2002: the case of Lima, Habitat International, 28 (2), 289-300.

Capozza, D.R., \& Helsley, R.W. (1989). The fundamentals of land prices and urban growth. Journal of Urban Economics, 26(3), 295-306.

Capozza, D.R., \& Sick, G.A. (1991). Valuing Long-Term Leases: The Option to Redevelop. Journal of Real Estate Finance and Economics, 4, 209-223.

Case, K., \& Shiller, R. (2003). Is There a Bubble in the Housing Market?/Comments and Discussion. Brookings Papers on Economic Activity(2), 299.

Chan, H.L., Lee, S.K., \& Woo, K.Y. (2001). Detecting rational bubbles in the residential housing markets of Hong Kong. Economic Modelling, 18(1), 61.

Chang, C.O., Chen, M.C., Teng, H.J., \& Yang, C.Y. (2009). Is There a Housing bubble in Taipei? Housing Price vs.Rent and Housing Price vs. Income. Journal of Housing Studies, 18(2), 1-22.

Chang, C.O., Yang, C.H. \& Hung, Y.R. (2008). Developing, Assessment and Integration of the Exist and Presale Housing Price Indexes-The Case of Taipei City. Journal of Housing Studies, 17(2), 13-35.

Chau, K.W. (1997) "Political uncertainty and the real estate risk premium in Hong Kong", Journal of Real Estate Research, 13, 3, 297 - 316.

Chau, K.W., Wong, S.K. Yiu, C.Y. and Leung, H.F. (2005) Real Estate Price Indices in Hong Kong, Journal of Real Estate Literature, 13(3), 337-356.

Clapp, J.M. and Salavei, K. (2010), “Hedonic pricing with redevelopment options: A 
new approach to estimating depreciation effects," Journal of Urban Economics, 67, 3, pp.362-377.

Davis, M., and Heathcote, J. (2007). The price and quantity of residential land in the United States. Journal of Monetary Economics 54 (8), 2595 - 2620.

De Souza, F.A..M. (1998) Land Tenure Security and Housing Improvements in Recife, Brazil, Habitat International, 23(1), 19-33.

Diba, B.T., \& Grossman, H.I. (1988). Explosive Rational Bubbles In Stock Prices? The American Economic Review, 78(3), 520.

Fernández-Kranz, D., \& Hon, M.T. (2006). A Cross-Section Analysis of the Income Elasticity of Housing Demand in Spain: Is There a Real Estate Bubble? The Journal of Real Estate Finance and Economics, 32(4), 449-470.

Flood, R.P., \& Hodrick, R.J. (1986). Asset Price Volatility, Bubbles, and Process Switching. The Journal of Finance, 41(4), 831.

Froot, K.A., \& Obstfeld, M. (1991). Intrinsic Bubbles: The Case of Stock Prices. The American Economic Review, 81(5), 1189-1189.

Hamilton, J.D. (1985). Uncovering Financial Market Expectations of Inflation. The Journal of Political Economy, 93(6), 1224.

Hatzvi, E., \& Otto, G. (2008). Prices, Rents and Rational Speculative Bubbles in the Sydney Housing Market. Economic Record, 84(267), 405.

Hui, E.C.M., \& Shen, Y. (2006). Housing Price Bubbles in Hong Kong, Beijing and Shanghai: A Comparative Study. The Journal of Real Estate Finance and Economics, 33(4), 299-327.

Hulme, D. (1996). Explosion of Japan"s 'land myth'. Asian Business, 32(7), 53.

Kawai M. (2008). Towards a regional exchange rate regime in East Asia. Pacific Economic Review, 13 (1), 83 - 103.

Khemroa, B.H.S. and Payne, G. (2004) Improving tenure security for the urban poor in Phnom Penh, Cambodia: an analytical case study, Habitat International, 28 (2), 181-201.

Kwok, R.Y.W. (2005). Globalizing Taipei: the political economy of spatial development.

Olima, W.H.A. \& Obala L.M. (1999) The Effect of Existing Land Tenure Systems on Urban Land Development: A Case Study of Kenya's Secondary Towns, with Emphasis on Kisumu, Habitat International, 23(1), 113-124.

Painter, G..L. Yang, and Z. Yu (2004) “Homeownership Determinants for Chinese Americans: Assimilation, Ethnic Concentration, and Nativity.” Real Estate Economics 32(3):509-539.

Porio, E. \& Crisol, C. (2004) Property rights, security of tenure andthe urban poor in Metro Manila, Habitat International, 28 (2), 203-219. 
Quigley, J.M. (1999). Real estate prices and economic cycles. International Real Estate Review, 2(1), 1-20.

Shiller, B. J. (2003), From Efficient Markets Theory to Behavioral Finance Journal of Economic Perspectives, 17(1) 83-104.

Siegel, J. J. (2003) What Is an Asset Price Bubble? An Operational Definition, European Financial Management, 9 (1), 2003, 11-24

Sivam, A., Evans, D., King, R., \& Young D. (2001) An approach to improved housing delivery in large cities of less developed countries, Habitat International, 25 (1), 99-113.

Smith, M.H., Smith, G.., Mayer, C., \& Shiller, R.J. (2006). Bubble, Bubble, Where"s the Housing Bubble?. Brookings Papers on Economic Activity, (37(1), 1-68.

Stiglitz, J.E. (1990). Symposium on Bubbles. Journal of Economic Perspectives, 4(2), 13-18.

Tsai, I.C., \& Peng, C.W. (2011). Bubbles in the Taiwan housing market: The determinants and effects. Habitat International, 35(2), 379-390.

Tu, Y. and Bao, H.X.H. (2009) Property Rights and Housing Value: The Impacts of Political Instability, Real Estate Economics, 37(2), 235-257.

Wong, S.K., Chau, K.W., Yiu, C.Y. \&and Yu, M.K.W. (2008) "Intergenerational Discounting: A Case from Hong Kong". Habitat International, 32 (3): 283-292.

Wu, Y. (1997). Rational bubbles in the stock market: Accounting for the U.S. stock-price volatility. Economic Inquiry, 35(2), 309.

Xiao, Q., \& Tan, G. K. R. (2007). Signal Extraction with Kalman Filter: A Study of the Hong Kong Property Price Bubbles. Urban Studies 44(4), 865-888.

Yiu, C.Y. (2008). Housing price gradient changes between Macau and Hong Kong: a neighboring city effect. International Journal of Housing Markets and Analysis, 1(2), 195 - 206. 